\title{
DYNAMICALLY LOADED BRANCHED AND INTERSECTING CRACKS
}

\begin{abstract}
The boundary element method (BEM) is applied to analysis of statically and dynamically loaded plates with branched and intersecting cracks. The numerical solution is obtained by discretization of external boundaries and crack surfaces using quadratic three-node boundary elements. The problem of coincident crack boundaries is solved by the dual BEM in which for nodes on crack surfaces simultaneously the displacement and the traction boundary integral equations are applied. The dynamic problem is solved by using the Laplace transform method and the solution in the time domain is computed by the Durbin numerical inversion method. The Laplace transform method gives very stable and accurate results and requires small computer memory. Static stress intensity factors (SIF) are computed by the path independent J-integral and dynamic SIF by the crack opening displacement (COD) method. Numerical examples of a branched crack in a rectangular plate and a star-shaped crack in a square plate are presented. Static SIF are compared with available results presented in literature showing good agreement. The maximum dynamic SIF are approximately two times larger than the corresponding static SIF. The influences of angles between branches of the crack and dimensions of the plate for the star-shaped crack on dynamic SIF are analyzed.
\end{abstract}

Keywords: fracture, stress intensity factor (SIF), boundary element method (BEM), Laplace transform method

\section{Introduction}

Branched and intersecting cracks may appear in a plate because of defects in the material or damage during the service life of the component. The stress state in the vicinity of the crack tips are characterized by stress intensity factors (SIF). The values of SIF decide about possible growth of the cracks.

Single branched or intersecting cracks in finite or infinite plates statically loaded were analyzed in several works. Cheung et al. [1] formulated the stress functions, which consists of two parts: a solution of the Fredholm integral equation for the crack problem in an infinite plate and the weighted residual

\footnotetext{
${ }^{1}$ Corresponding author / autor do korespondencji: Piotr Fedeliński, Silesian University of Technology, Konarskiego 18A, 44-100 Gliwice, Poland; phone: 4832237 1635; Piotr.Fedeliński@polsl.pl
} 
method for a general plane problem. The method was applied to crucifix cracks, two perpendicular cracks and star-shaped cracks in finite plates. Isida i Noguchi [2] presented the analysis based on the body force method combined with the perturbation procedure which gives the stress intensity factors by the power series formulae. Numerical results for various symmetrical and unsymmetrical branched cracks under three fundamental loadings at infinity are presented. Chen and Hasebe [3] applied a point dislocation at the branch point and distributed dislocations along the branches. Next they formulated a singular integral equation to solve the branch crack problem. The method was applied to starshaped cracks, symmetric branched cracks and two intersecting cracks. Daux et al. [4] presented the extended finite element method (X-FEM) to analysis of cracks with multiple branches and cracks emanating from holes. A standard displacement approximation was enriched by incorporating additional discontinuous functions. The method allows the modelling of discontinuities independently of the mesh. Tan et al. [5] developed the method in which the original crack problem is decomposed into two problems, and the hybrid boundary node method is used to model the finite domain of the body without a crack and the displacement discontinuity method to analyze the crack. The results are added and compared with the boundary conditions of the original problem. The method was applied to a branched crack and star-shaped crack in a finite plate. The analysis of branched and intersecting stationary cracks subjected to dynamic loads has not been presented in the literature.

In the present work the boundary element method (BEM) is applied to analysis of statically and dynamically loaded branched and intersecting cracks in finite plates. The crack problem is solved by the dual BEM which was developed for static loading by Portela et al. [6] and for dynamic loading by Fedeliński et al. [7]. An overview of different BEM approaches in dynamic fracture mechanics was presented by Fedeliński [8], [9], [10]. In this work the Laplace transform method is applied to analysis of a branched crack in a rectangular plate and a star-shaped crack in a square plate. The influence of geometry of cracked plates on dynamic stress intensity factors is analyzed.

\section{Laplace transform boundary element method}

Consider a homogeneous and isotropic linear elastic body enclosed by a boundary $\Gamma$. For a body which is not subjected to body forces and which has zero initial displacements and velocities, the Laplace transform of the displacements of points $x^{\prime}$ and $x^{\prime \prime}$ on smooth crack surfaces, can be represented by the following boundary integral equation [7] 


$$
\begin{aligned}
\frac{1}{2} \bar{u}_{i}\left(x^{\prime}, s\right)+\frac{1}{2} \bar{u}_{i}\left(x^{\prime \prime}, s\right)= & \int_{\Gamma} \bar{U}_{i j}\left(x^{\prime}, x, s\right) \bar{t}_{j}(x, s) d \Gamma(x)- \\
& \int_{\Gamma} \bar{T}_{i j}\left(x^{\prime}, x, s\right) \bar{u}_{j}(x, s) d \Gamma(x)
\end{aligned}
$$

where $\bar{U}_{i j}\left(x^{\prime}, x, s\right), \bar{T}_{i j}\left(x^{\prime}, x, s\right)$ are the Laplace transforms of fundamental solutions of elastodynamics [9], $\bar{u}_{j}(x, s), \bar{t}_{j}(x, s)$ are the Laplace transforms of the displacements and tractions respectively, at the boundary, $s$ is the integral transform parameter.

The Laplace transform of the traction equation for points which belong to smooth crack surfaces is

$$
\begin{array}{r}
\frac{1}{2} \bar{t}_{j}\left(x^{\prime}, s\right)-\frac{1}{2} \bar{t}_{j}\left(x^{\prime \prime}, s\right)=n_{i}\left(x^{\prime}\right)\left[\int_{\Gamma} \bar{U}_{k i j}\left(x^{\prime}, x, s\right) \bar{t}_{k}(x, s) d \Gamma(x)-\right. \\
\left.\int_{\Gamma} \bar{T}_{k i j}\left(x^{\prime}, x, s\right) \bar{u}_{k}(x, s) d \Gamma(x)\right]
\end{array}
$$

where $\bar{U}_{k i j}\left(x^{\prime}, x, s\right)$ and $\bar{T}_{k i j}\left(x^{\prime}, x, s\right)$ are the Laplace transforms of other fundamental solutions of elastodynamics [9].

The numerical solution of a general mixed-mode crack problem is obtained after discretizing boundary quantities. The boundary $\Gamma$ of the body is divided into boundary elements. Quadratic elements are used for the discretization of the boundary. The displacements and tractions are interpolated using: continuous elements for the external boundary and discontinuous elements on the crack faces. Displacements and tractions are approximated within each element using interpolation functions. A distinct set of boundary integral equations is obtained by applying the displacement equation for nodes along the external boundary and along the crack and the traction equation for the nodes along the crack. The set of discretized boundary integral equations can be written in matrix form as

$$
\overline{\boldsymbol{H}} \overline{\boldsymbol{u}}=\overline{\boldsymbol{G}} \overline{\boldsymbol{t}}
$$

where $\overline{\boldsymbol{u}}$ and $\overline{\boldsymbol{t}}$ contain nodal values of the transformed displacements and tractions respectively, and $\overline{\boldsymbol{H}}$ and $\overline{\boldsymbol{G}}$ depend on integrals of the transformed fundamental solutions and the interpolating functions. The matrices $\overline{\boldsymbol{H}}$ and $\overline{\boldsymbol{G}}$ are reordered according to the boundary conditions to give new matrices $\overline{\boldsymbol{A}}$ and $\overline{\boldsymbol{B}}$. The matrix $\overline{\boldsymbol{A}}$ is multiplied by the vector $\overline{\boldsymbol{x}}$ of unknown transformed displacements and tractions and $\overline{\boldsymbol{B}}$ by the vector $\overline{\boldsymbol{y}}$ of the known transformed boundary conditions, as follows 


$$
\bar{A} \bar{x}=\bar{B} \bar{y}
$$

or

$$
\overline{\boldsymbol{A}} \overline{\boldsymbol{x}}=\overline{\boldsymbol{f}}
$$

where $\overline{\boldsymbol{f}}=\overline{\boldsymbol{B}} \overline{\boldsymbol{y}}$ is a known vector. The matrix equation (5) is solved giving the unknown transformed displacements and tractions for a particular integral transform parameter. For a simple temporal variation of the prescribed boundary conditions their integral transforms can be calculated analytically. In order to obtain the unknown displacements and tractions as functions of time, the unknown transformed variables must be computed for a series of parameters. The final time-dependent solution can be obtained from the numerical Durbin inversion.

\section{Numerical examples}

Two numerical examples are considered: a branched crack in a rectangular plate and a star-shaped crack in a square plate. The material of the plate has the following material properties: the Young modulus $E=200 \mathrm{GPa}$, the Poisson ratio $v=0.3$, mass density $\rho=8000 \mathrm{~kg} / \mathrm{m}^{3}$ and the plate is in the plain strain conditions. The plates are loaded by the Heaviside time dependent uniformly distributed tractions $p$ applied at the initial time $t=0$. The numerical solution is obtained using 50 Laplace parameters and the time step $\Delta t=0.2 \mu \mathrm{s}$. Static SIF are computed using the path independent J-integral and the dynamic SIF using crack opening displacements.

\subsection{Branched crack in a rectangular plate}

The horizontal branch has the length $a$ and the branches of length $b$ are inclined at the angle $\alpha=\pi / 4 \mathrm{rad}$, as shown in Fig. 1a. It is assumed that the branches are equal $a=b=1 \mathrm{~cm}$. The crack is in the center of a rectangular plate of width $2 w$ and the height $2 h$ and the ratio of dimensions is $h / w=4 / 5$ and $a / w=0.5$. Two horizontal edges of the plate are loaded in the vertical direction. The plate is divided into 140 boundary elements ( 80 for the external boundary and 10 for each crack edge). The stress intensity factors are normalized with respect to the SIF $K_{o}=p \sqrt{\pi c}$, where $2 c$ is the width of the crack in the horizontal direction. 
a)

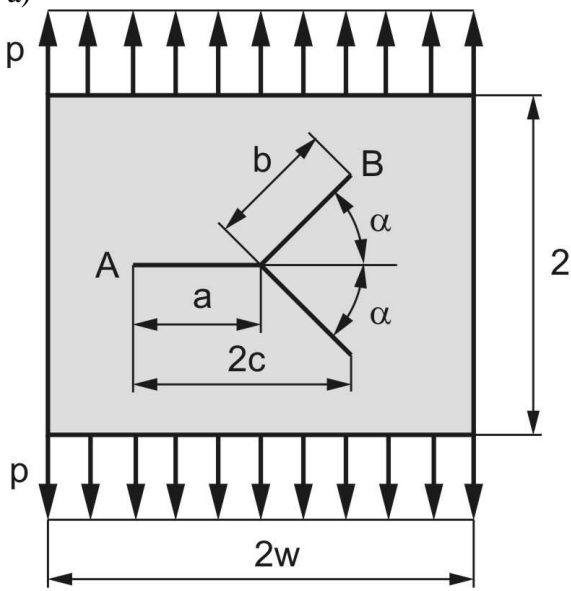

b)

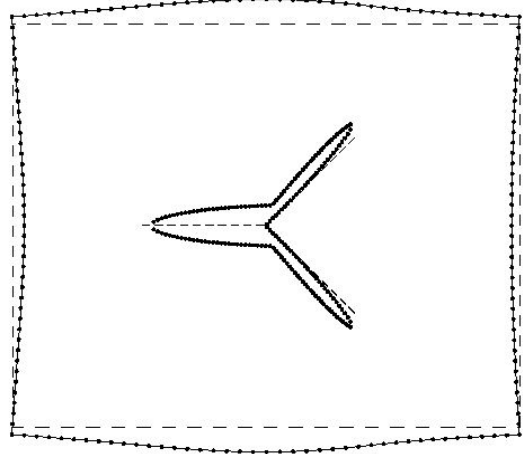

Fig. 1. Branched crack in a rectangular plate: (a) dimensions of the plate and loading, (b) initial (dashed line) and deformed shape (continuous line) of the plate

Rys. 1. Pękniecie rozgałęzione w tarczy prostokątnej: (a) wymiary tarczy i obciążenie, (b) początkowy (linia przerywana) i odkształcony kształt tarczy (linia ciągła)

Initially the plate is subjected to the static loading. The computed normalized SIF for the crack tips $A$ and $B$ are presented in Table 1 and compared with the results published by Daux et al. [4] who used the extended finite element method (X-FEM). The agreement of the results is satisfactory. In Fig. 1b the initial and the deformed shape are shown.

Table 1. Static normalized stress intensity factors

Tabela 1. Statyczne znormalizowane współczynniki intensywności naprężeń

\begin{tabular}{|c|c|c|c|}
\hline SIF & $\boldsymbol{K}_{\boldsymbol{I}} / \boldsymbol{K}_{\boldsymbol{o}}(\boldsymbol{A})$ & $\boldsymbol{K}_{\boldsymbol{I}} / \boldsymbol{K}_{\boldsymbol{o}}(\boldsymbol{B})$ & $\boldsymbol{K}_{\boldsymbol{I I}} / \boldsymbol{K}_{\boldsymbol{o}}(\boldsymbol{B})$ \\
\hline present & 1.555 & 0.770 & 0.806 \\
\hline Daux et al. [4] & 1.368 & 0.634 & 0.723 \\
\hline
\end{tabular}

The normalized dynamic stress intensity factors for the crack tips $A$ and $B$ are presented in Fig. 2. Initially when the longitudinal wave travels from the loaded boundary to the crack tips the DSIF are zero. The DSIF for the crack tip $A$ are larger than for the crack tip $B$. The maximum values of dynamic DSIF are approximately two times larger than the corresponding static values of SIF.

The influence of the angle $\alpha$ between crack branches on the normalized DSIF at the crack tip $B$ is shown in Fig. 3. The DSIF are calculated for three angles $\alpha=\pi / 6, \pi / 4, \pi / 3 \mathrm{rad}$. The DSIF $K_{I} / K_{o}$ decrease with increasing angle $\alpha$ and $K_{I I} / K_{o}$ increase. 


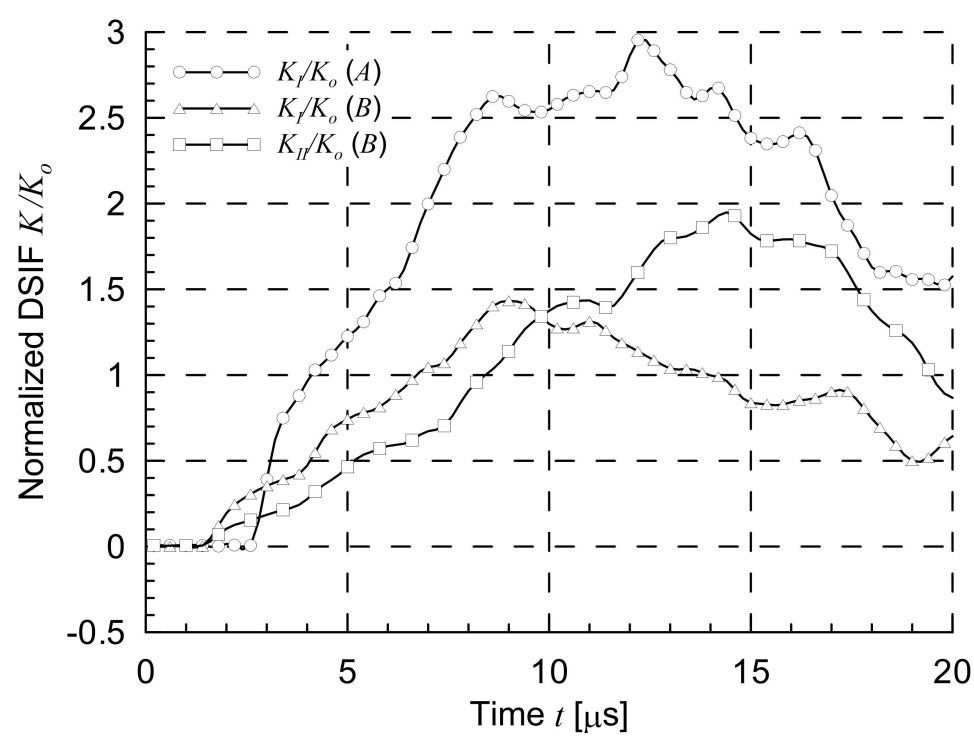

Fig. 2. Normalized dynamic stress intensity factors for the branched crack in a rectangular plate

Rys. 2. Znormalizowane dynamiczne współczynniki intensywności naprężeń pęknięcia rozgałęzionego $\mathrm{w}$ tarczy prostokątnej

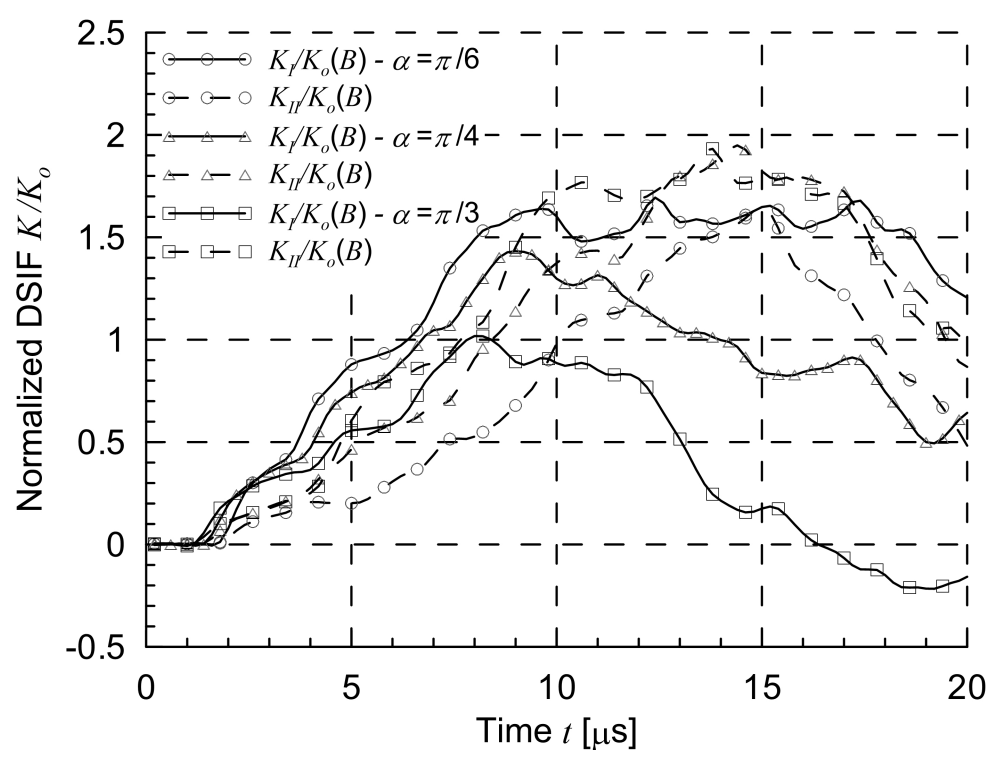

Fig. 3. Influence of the angle $\alpha$ between the crack branches on the normalized dynamic stress intensity factors at the crack tip $B$ for the branched crack in a rectangular plate

Rys. 3. Wpływ kąta $\alpha$ między pęknięciami na znormalizowane dynamiczne współczynniki intensywności naprężeń w wierzchołku $B$ pęknięcia rozgałęzionego w tarczy prostokątnej 


\subsection{Star-shaped crack in a square plate}

The branches of the star-shaped crack have the length $a$ and the branches are inclined at the angle $\alpha=\pi / 3 \mathrm{rad}$, as shown in Fig. 4a. It is assumed that the branches are equal $a=1 \mathrm{~cm}$. The crack is in the center of a square plate of width $2 w$ and the ratio of dimensions is $a / w=0.5$. The plate is subjected to biaxial tension. The plate is divided into 200 boundary elements ( 80 for the external boundary and 10 for each crack edge). The stress intensity factors are normalized with respect to the SIF $K_{o}=p \sqrt{\pi a}$.

a)

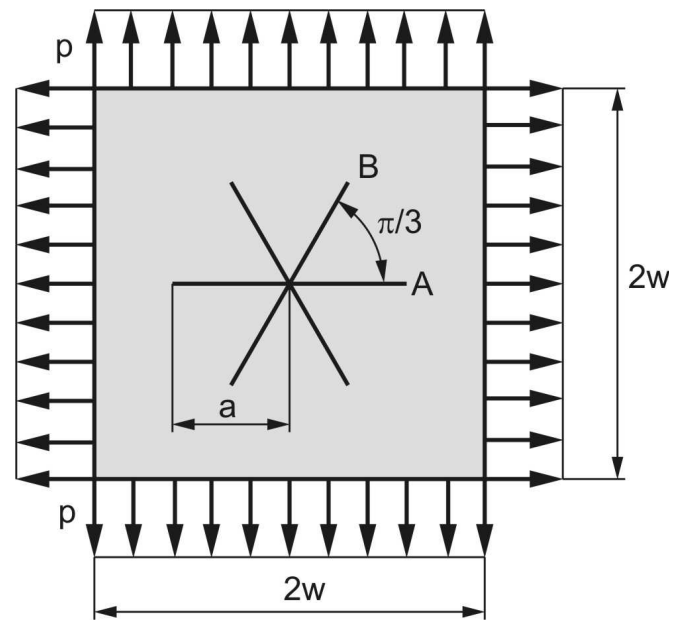

b)

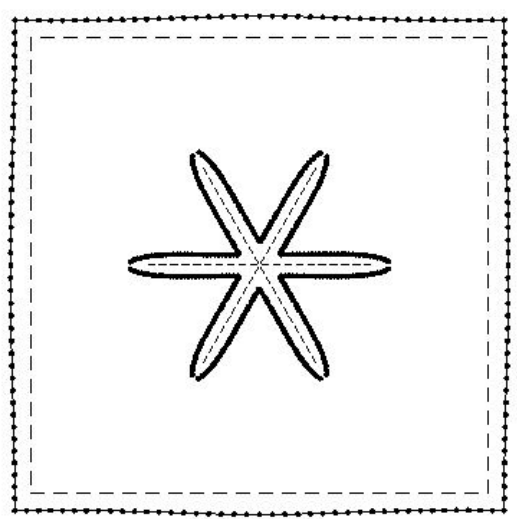

Fig. 4. Star-shaped crack in a square plate: (a) dimensions of the plate and loading, (b) initial (dashed line) and deformed shape (continuous line) of the plate

Rys. 4. Pękniecie gwiaździste w tarczy kwadratowej: (a) wymiary tarczy i obciążenie, (b) początkowy (linia przerywana) i odkształcony kształt tarczy (linia ciągła)

Initially the plate is subjected to the static loading. The computed normalized SIF for the crack tips $A$ and $B$ are presented in Table 2 and compared with the results published by Daux et al. [4] who used the extended finite element method (X-FEM) and Cheung et al. [1], who used the Fredholm integral equation method and the weighted residual method. The agreement of the results is very good. In Fig. $4 \mathrm{~b}$ the initial and the deformed shape are shown. 
Table 2. Static normalized stress intensity factors

Tabela 2. Statyczne znormalizowane współczynniki intensywności naprężeń

\begin{tabular}{|c|c|c|c|}
\hline SIF & $\boldsymbol{K}_{\boldsymbol{I}} / \boldsymbol{K}_{\boldsymbol{o}}(\boldsymbol{A})$ & $\boldsymbol{K}_{\boldsymbol{I}} / \boldsymbol{K}_{\boldsymbol{o}}(\boldsymbol{B})$ & $\boldsymbol{K}_{\boldsymbol{I I}} / \boldsymbol{K}_{\boldsymbol{o}}(\boldsymbol{B})$ \\
\hline present & 0.898 & 0.928 & 0.020 \\
\hline Daux et al. [4] & 0.893 & 0.921 & 0.017 \\
\hline Cheung et al. [1] & 0.885 & 0.909 & 0.017 \\
\hline
\end{tabular}

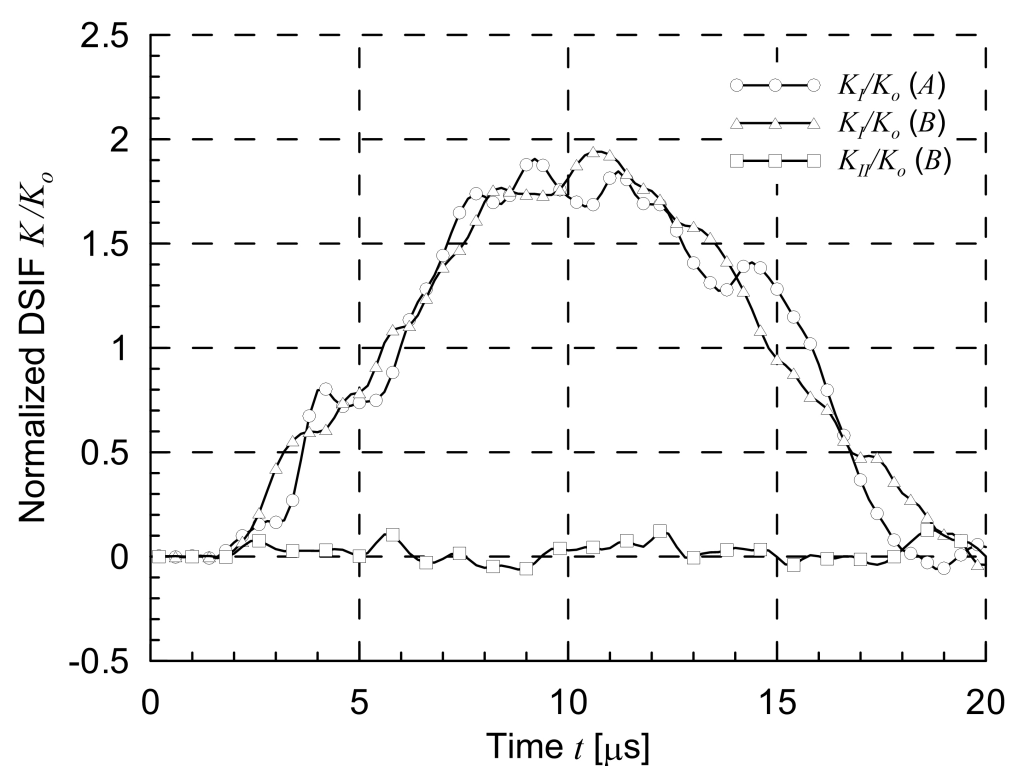

Fig. 5. Normalized dynamic stress intensity factors for the star-shaped crack in a square plate

Rys. 5. Znormalizowane dynamiczne współczynniki intensywności naprężeń pęknięcia gwiaździstego w tarczy kwadratowej

The normalized dynamic stress intensity factors for the crack tips $A$ and $B$ are presented in Fig. 5. Initially when the longitudinal wave travels from the loaded boundary to the crack tips the DSIF are zero. The DSIF $K_{I} / K_{o}$ for the crack tips $A$ and $B$ have similar time dependence. The DSIF for the crack tip $B K_{I I} / K_{o}$ are much smaller than $K_{I} / K_{o}$. The maximum values of dynamic DSIF are approximately two times larger than the corresponding static values of SIF.

The influence of the dimension of the plate $w$ on normalized DSIF at the crack tip $A$ is shown in Fig. 6. The DSIF are calculated for three different dimensions of the plate $w / a=2,3,4$ and $a=1 \mathrm{~cm}$. When the dimension of the plate is large the longitudinal wave arrives late at the crack tip. The time dependence and the maximum value of DSIF after the arrival of the wave at the crack tip is similar for different dimensions of the plate. 


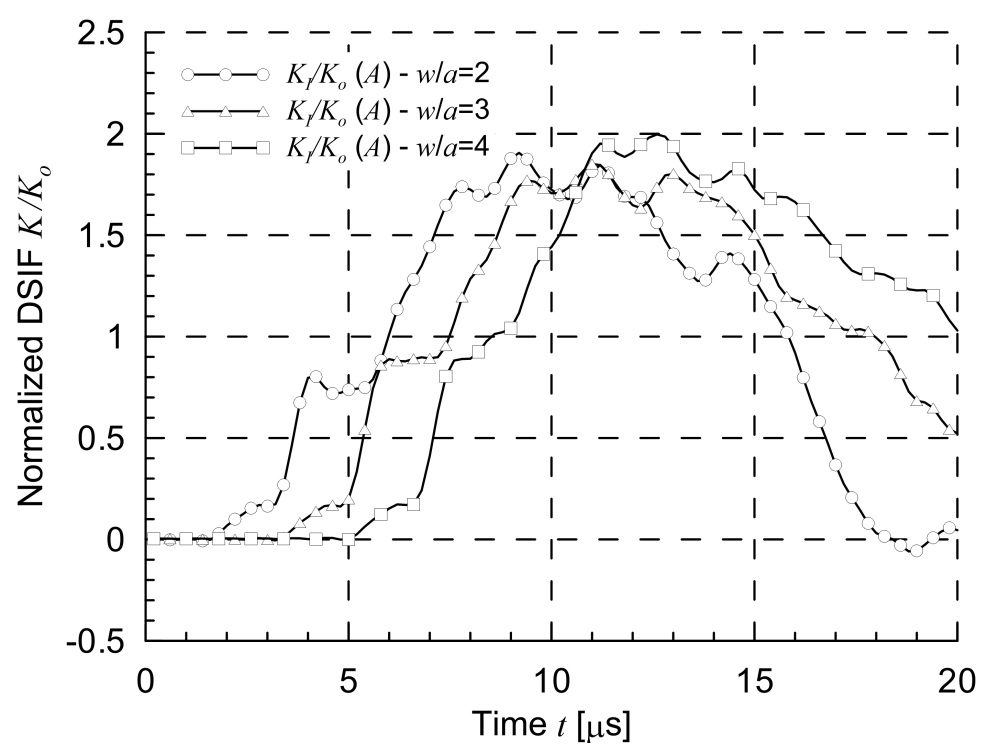

Fig. 6. Influence of the dimension of the plate $w$ on normalized dynamic stress intensity factors at the crack tip $A$ for the star-shaped crack in a square plate

Rys. 6. Wpływ wymiaru tarczy $w$ na znormalizowane dynamiczne współczynniki intensywności naprężeń w wierzchołku $A$ pęknięcia gwiaździstego w tarczy kwadratowej

\section{Conclusions}

The numerical examples demonstrate that the SIF for static loading obtained by the BEM agree well with the available results presented in literature. The solutions obtained by the Laplace transform BEM are stable. The maximum values of dynamic SIF are about two times larger than the static SIF.

Acknowledgement: The scientific research is financed by National Science Centre, Poland in years 2016-2019, grant no. 2015/19/B/ST8/02629.

\section{Literature}

[1] Cheung Y. K., Woo C. W., Wang Y. H.: A general method for multiple crack problems in a finite plate, Computational Mechanics, vol. 10, 1992, pp. 335-343.

[2] Isida M., Noguchi H.: Stress intensity factors at tips of branched cracks under various loadings, International Journal of Fracture, vol. 54, 1992, pp. 293-316.

[3] Chen Y. Z., Hasebe N.: New integration scheme for the branch crack problem, Engineering Fracture Mechanics, vol. 52, 1995, pp. 791-801.

[4] Daux Ch., Moes N., Dolbow J., Sukumar N., Belytschko T.: Arbitrary branched and intersecting cracks with the extended finite element method, International Journal for Numerical Methods in Engineering, vol. 48, 2000, pp. 1741-1760. 
[5] Tan F., Zhang Y., Li Y.: An improved hybrid boundary node method for 2D crack problems, Archives of Applied Mechanics, vol. 85, 2015, pp. 101-116.

[6] Portela, A., Aliabadi, M. H., Rooke, D. P.: The dual boundary element method: effective implementation for crack problems, International Journal for Numerical Methods in Engineering, vol. 33, 1992, pp. 1269-1287.

[7] Fedeliński, P., Aliabadi, M. H., Rooke, D.P.: The Laplace transform DBEM method for mixed-mode dynamic crack analysis, Computers and Structures, vol. 59, 1996, pp. 1021-1031.

[8] Fedeliński P.: Boundary element method in dynamic analysis of cracks, Engineering Analysis with Boundary Elements, vol. 28, 2004, pp. 1135-1147.

[9] Fedeliński P.: The boundary element method in dynamic analysis of deformable structures with cracks, Scientific Papers of the Silesian University of Technology, Mechanics, vol. 137, Gliwice 2000 (in Polish).

[10] Fedeliński P.: Boundary element method in dynamics of deformable structures, Scientific Papers of the Silesian University of Technology, Mechanics, vol. 622, Gliwice 2016 (in Polish).

\section{ROZGAŁĘZIONE I PRZECINAJĄCE SIĘ PĘKNIĘCIA OBCIĄŻONE DYNAMICZNIE}

\section{Streszczenie}

Metodę elementów brzegowych (MEB) zastosowano do analizy obciążonych statycznie i dynamicznie tarcz z pęknięciami rozgałęzionymi i przecinającymi się. Rozwiązanie numeryczne otrzymano w wyniku dyskretyzacji brzegów zewnętrznych tarczy i krawędzi pęknięć z zastosowaniem kwadratowych trójwęzłowych elementów brzegowych. Zastosowano sformułowanie duale MEB do analizy pokrywających się krawędzi pęknięcia, w którym stosuje się jednocześnie dla węzłów pęknięcia brzegowe równanie całkowe przemieszczeń i sił powierzchniowych. Zagadnienie dynamiczne analizowano metodą transformacji Laplace'a, a rozwiązanie w dziedzinie czasu wyznaczono metodą numerycznej transformacji odwrotnej Durbina. Metoda transformacji Laplace'a pozwala na wyznaczenie stabilnego i dokładnego rozwiązania i wymaga małej pamięci komputerowej. Statyczne współczynniki intensywności naprężeń (WIN) obliczono za pomocą J-całki niezależnej od konturu całkowania, a dynamiczne WIN na podstawie rozwarcia krawędzi pęknięcia. Przedstawiono przykłady numeryczne rozgałęzionego pęknięcia w tarczy prostokątnej i pęknięcia gwiaździstego w tarczy kwadratowej. Statyczne WIN porównano z wynikami dostępnymi w literaturze, wykazując dobrą zgodność rozwiązań. Maksymalne wartości dynamicznych WIN są około dwukrotnie większe niż odpowiednie statyczne WIN. Badano wpływ kąta między pęknięciami rozgałęzionymi i wielkości tarczy z pęknięciem gwiaździstym na dynamiczne WIN.

Słowa kluczowe: pękanie, współczynnik intensywności naprężeń (WIN), metoda elementów brzegowych (MEB), metoda transformacji Laplace'a

Przestano do redakcji: $13.02 .2017 \mathrm{r}$.

Przyjęto do druku: 28.04.2017 r. 